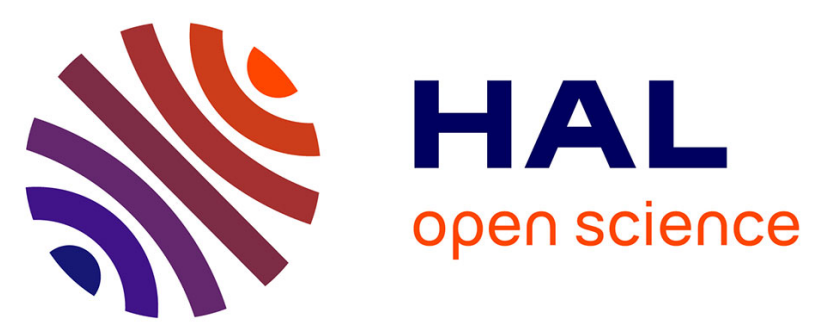

\title{
Simulation of consumer exposure to deoxynivalenol according to wheat crop management and grain segregation: Case studies and methodological considerations
}

Marianne Le Bail, Philippe Verger, Thierry Doré, Jean-François Fourbet, Agnès Champeil, Renaud Ioos, Jean-Charles Leblanc

\section{To cite this version:}

Marianne Le Bail, Philippe Verger, Thierry Doré, Jean-François Fourbet, Agnès Champeil, et al.. Simulation of consumer exposure to deoxynivalenol according to wheat crop management and grain segregation: Case studies and methodological considerations. Regulatory Toxicology and Pharmacology, 2005, 42 (3), pp.253-259. 10.1016/j.yrtph.2005.04.001 . hal-01354876

\section{HAL Id: hal-01354876}

https://hal-agroparistech.archives-ouvertes.fr/hal-01354876

Submitted on 19 Aug 2016

HAL is a multi-disciplinary open access archive for the deposit and dissemination of scientific research documents, whether they are published or not. The documents may come from teaching and research institutions in France or abroad, or from public or private research centers.
L'archive ouverte pluridisciplinaire HAL, est destinée au dépôt et à la diffusion de documents scientifiques de niveau recherche, publiés ou non, émanant des établissements d'enseignement et de recherche français ou étrangers, des laboratoires publics ou privés.

\section{(1) (1) $\$$}

Distributed under a Creative Commons Attribution - NonCommercial - NoDerivatives $\mid 4.0$ 


\subsection{6/j.yrtph.2005.04.001}

Simulation of consumer exposure to deoxynivalenol according to wheat crop management and grain segregation: case studies and methodological considerations

Marianne Le Bail(1), Philippe Verger(2), Thierry Doré(3), Jean-François Fourbet(4), Agnès Champeil(4), Renaud Ioos(5), Jean-Charles Leblanc(2)

(1) INA P-G, UMR SAD APT, 16 rue C. Bernard, 75231 Paris Cedex 05, France

(2) INRA, UMR Mét@risk, 16 rue C. Bernard, 75231 Paris Cedex 05, France

(3) INA P-G, UMR d'agronomie, B.P. 1, 78850 Thiverval-Grignon, France

(4) INRA, UMR d'agronomie, B.P. 1, 78850 Thiverval-Grignon, France

(5) LNPV UMAF, Domaine de Pixérécourt, 54220 Malzéville, France

Correspondence: Marianne Le Bail, UMR SAD-APT, INA Paris-Grignon, 16 rue C. Bernard, 75231 Paris Cedex 05, France. Tel: 01440816 87; Fax: 01440816 57; E-mail: lebail@inapg.inra.fr

Word count for abstract: 172

Word count for text: 3250

Word count for references: 1150 


\begin{abstract}
We combined agronomic data and a model simulating exposure based on consumption data to assess the impact of crop management and grain segregation procedures on consumer exposure to deoxynivalenol. We used three scenarios of soil tillage at a regional scale and three scenarios of grain segregation for a supply area. The soil tillage scenarios were applied to a range of mean crop contamination levels, with various coefficients representing the degree of tillage. The grain segregation scenarios were applied to two real datasets of DON content distributions. We found that the increase in consumer exposure in response to increases in "risky" crop management practices such as direct-drilling depends largely on mean contamination and on the value of the tillage coefficient. The results for grain segregation procedures showed that exposure was most strongly affected by contamination distributions as the segregation procedure minimising risk differed for the two datasets.
\end{abstract}

Keywords: deoxynivalenol, consumer exposure, crop management, grain segregation, wheat, mycotoxin, Fusarium 


\section{Introduction}

Deoxynivalenol (DON) is a trichothecene occurring predominantly in cereal crops such as wheat, barley, oats, rye and maize. DON is produced mainly in the field by phythopathogenic or opportunistic species of fungi, which belong to the genus Fusarium. The toxicity of DON has been reviewed by WHO (1990), IARC (1993) and more recently by JECFA (2001). The acute effects of DON (nausea, vomiting, diarrhoea, abdominal pain etc.) are difficult to distinguish from the gastrointestinal effects of microbes and have been attributed to the presence of DON at concentrations of $3-93 \mathrm{mg} \cdot \mathrm{kg}^{-1}$ in grain for human consumption. DON has long-term toxic effects on the immune system, growth and reproduction. JECFA (2001) established a provisional maximum tolerable daily intake (PMTDI) of $1 \mu \mathrm{g} \cdot \mathrm{kg}^{-1}$ body weight based on a two-year study in mice and a safety factor of 100. Now that the risk has been assessed, risk management procedures are required to ensure that consumers are not exposed to levels of toxin exceeding this PMTDI. One of the key issues involved in setting standards is consideration of both the variability of measurement of DON concentration in grain and annual variation of the mean concentration of this mycotoxin, which may vary by a factor of five (Lauren et al., 1991, 1996; Scott, 1997). In practice, assuming a consumption of $175 \mathrm{~g}$ of wheat flour per day (GEMS Food, 2003) and a PMTDI of $60 \mu \mathrm{g} /$ day for an adult weighing 60 $\mathrm{kg}$, the maximum permissible concentration in wheat is $340 \mu \mathrm{g} \cdot \mathrm{kg}^{-1}$. However, it is difficult to respect this limit every year at field scale.

In recent years, agronomists have investigated the effects of farmers' practices on harvest quality. Most studies have focused on processing and organoleptic qualities (Habib et al., 1997; Virender, 2000); but recent studies have also considered aspects of food safety (Doré et al. 2002; Champeil, 2004). They have also taken into account the fact that crops produced by farmers are often collected by firms acting as middle-men and that production is generally 
divided into several batches with different levels of quality for different agro-industrial markets. For cereals for example, two main strategies may be used to improve the quality of production in the supply area: improvements in cropping systems and the use of good agricultural practices at field scale and/or optimizing crop segregation in country grain elevators (Habib et al., 1997; Le Bail \& Makowski, 2004). For example, it has been shown that in years in which DON levels exceed the limits set (Dowell et al., 1999), some US millers spend considerable amounts of money attempting to blend wheat to meet FDA (Food and Drug Administration) guidelines. It seems likely that it will become increasingly difficult in the future to use blending as an opportunist solution.

Research programmes carried out in the last 20 years have shown that wheat crop management affects the risk of contamination with Fusarium toxins at harvest. Preceding crop (Teich \& Hamilton, 1985; Krebs et al., 2000; Dill-Macky \& Jones, 2000), soil tillage (Teich \& Hamilton, 1985; Krebs et al., 2000; Schaafsma et al., 1998; Dill-Macky \& Jones, 2000; Champeil et al., 2004; Koch \& Pringas, 2004), fungicide application (Hardy et al., 1999; Simpson et al., 2001; Ioos et al., 2005), and wheat genotype (Jenny et al., 2000; Young, 2002) have all been shown to affect the level of grain contamination with DON.

In this study, we aimed to use current knowledge to identify and to discuss the effects on consumer exposure to the toxin DON of changes in farming practices or in crop segregation practices at country grain elevators.

\section{Materials and Methods}

Defining crop management scenarios

These scenarios concern the changes in crop management on plots harvested in the supply 
area of a country elevator. Reduced tillage and no-tillage systems are being used in increasingly large areas throughout the world (Derpsch \& Benites, 2003). As they are also known to have a most important impact on DON contamination, we therefore decided to assess the effects of the large-scale adoption of reduced tillage systems on consumer exposure to DON. Previous studies of wheat-grain DON contamination have reported differences between ploughed and no-tillage plots of various magnitudes, depending preceding crop (and year for the Champeil study): 1) zero to eight times more contamination in no-tillage plots than in ploughed plots (Champeil, 2004); 2) zero to three times more contamination in notillage plots (Koch \& Pringas, 2004, mean of a two-year experiment); 3) zero to 1.5 times more contamination in no-tillage plots (Dill-Macky \& Jones, 2000, mean of a three-year experiment with two levels of irrigation); 4) zero to eight times more contamination in notillage plots (Krebs et al., 2000). In all cases, the use of maize as the preceding crop led to the highest levels of grain contamination with DON. Thus, the adoption of no-tillage practices is likely to have a much greater effect on grain contamination with DON in maize cropping areas than in areas in which maize is rare. Based on these previous studies, no-tillage systems seem to display an average of three times more DON contamination of grain than ploughed systems.

We set up three scenarios, differing in the extent of conversion to no-tillage systems.

Scenario 1: all the plots of the area are ploughed (0\% no-tillage)

Scenario 2: half the area is ploughed (50\% no-tillage)

Scenario 3: all the plots are direct-drilled (100\% no-tillage) 
In each of these scenarios, all the wheat crops of the supply area are blended in a country grain elevator.

\section{Defining segregation scenarios}

The segregation of cereal crops in the crop supply system affects final batch quality, as batch contamination depends on mean grain contamination levels for each plot and plot production. The basic segregation scenario (scenario $a$ ) corresponds to the blending of all the wheat crops from a given crop supply area. This basic scenario was used for crop management scenarios 1-3. Two alternative scenarios were studied to assess the effects of alternative supply strategies on consumer exposure. Such alternative strategies have already been successfully explored to face processing quality problems in cereal crops (Le Bail, 1997). The first alternative scenario (scenario $b$ ) was defined based on preceding crop, which is known to have an effect on DON contamination. We studied preceding crop (maize vs. other crops) as it is easier to obtain precise information for this variable than for soil tillage for real farms. A second alternative scenario (scenario $c$ ) was defined based on data for the real grain contamination of each plot: all the plots of the crop supply area with grain contamination levels below $1250 \mu \mathrm{g} \cdot \mathrm{kg}^{-1}$ (discussed as a reference value in the EU for commercial transactions) were used to make a first batch, and the other plots were used to make a second batch. This strategy may be of value for limiting consumer exposure to DON, as grain contamination in farmers' fields within a crop supply area does not follow a normal distribution. The various data series available, recorded at national or regional level, show that this distribution seems to be log-normal (EU SCOOP 3.2.10; DGAL, 2004; Champeil, 2004). If this is indeed the case, then the rare fields with very high toxin content in a sample of fields are likely to have a major effect on the mean contamination level of the sample, and the 
segregation of these fields from the other fields should have a large, positive effect, reducing consumer exposure. The three scenarios are summarised as follows:

Scenario a: all the wheat crops of the area are blended in a single batch $A$ Scenario b: the plots of the area are divided into two classes according to preceding crop: batch $M$ (maize) for the plots with maize as a preceding crop and batch $O$ (others) for the other plots

Scenario $c$ : the plots of the area are divided in two classes according to the real grain contamination value to segregate two batches: batch $L$ (low) for the plots with grain contamination levels lower than $1250 \mu \mathrm{g} \cdot \mathrm{kg}^{-1}$, and batch $H$ (high) for the plots with contamination levels at or exceeding this threshold.

These three scenarios were applied to two distributions of grain contamination. For samples in DON was not detected (40\% of censored data in dataset 1 , and $5 \%$ in dataset 2 ) we assumed contamination at half the detection limit (not detected $=1 / 2$ limit of detection (LOD)). For plots with DON levels below the quantification limit, we assumed contamination at half this limit (< limit of quantification $(\mathrm{LOQ})=1 / 2$ LOQ) according to the IPCS/Gems/food recommendations of the 1995 Euro Workshop. The first data set used was a sample of 17 organic wheat fields harvested in the western part of the Paris Basin in 2002. Grain DON content for dataset 1 ranged from 15 to $2250 \mu \mathrm{g} \cdot \mathrm{kg}^{-1}$ (15 is half the LOD for dataset 1 ), with $15 \mu \mathrm{g} . \mathrm{kg}^{-1}$ as a median value. The second data set was a sample of 21 wheat fields harvested in France in 2002. Grain DON content for dataset 2 ranged from 10 to $16685 \mu \mathrm{g} . \mathrm{kg}^{-1}$ (10 is half the LOD for dataset 2), with $135 \mu \mathrm{g} \cdot \mathrm{kg}^{-1}$ as a median value. The mean values of grain contamination for the various batches, for both data sets, are shown in table 1 . The means were estimated assuming equal yields for all plots. 


\section{Consumer exposure assessment}

We assessed consumer exposure levels based on the combination of food consumption data and the various levels of grain contamination obtained with the six scenarios. Food consumption data are released by the French national and individual survey of food consumption, called "INCA", conducted in 1999 in 3003 subjects aged three years and over (Crédoc-AFSSA-DGAL, 2000). In this survey, 2492 consumers of cereal products were identified. As deoxynivalenol is mostly found in wheat flour and we had contamination data only for the raw material used to produce flour, wheat grains we introduced a weighting factor to take into account the percentage of flour in cereal-based products. Consumption data for cereal-based products were then recalculated from the original consumption level reported in each food survey, by integrating the percentage of wheat flour needed to produce cereal-based products. We did this by assuming that $40 \%$ of biscuits, composite dishes (such as pizza or sandwiches) and breakfast cereals, $80 \%$ of bread, 95\% of pasta and $100 \%$ of cereals (semolina, couscous etc.) are constituted by wheat flour (Leblanc et al., 2002). The mean, median, $90^{\text {th }}, 95^{\text {th }}$ and $97.5^{\text {th }}$ percentiles of the distribution of daily wheat flour consumption were examined (Table 2). Estimated daily exposure was assessed by multiplying the mean concentrations of DON in wheat by the amount of food, correcting for the approximate proportion of flour in the food consumed daily by each consumer. The DON content in flour was determined using a corrective coefficient of 0.44 (Neira et al., 1997) applied to grain content, to take into account the effects of processing. This calculation provides a realistic estimation of exposure, for comparisons with long-term toxicological effects (JEFCA, 2001). 


\section{Results and discussion}

We assessed consumer exposure to DON according to flour consumption and the three scenarios of crop management at a regional scale (Table 3), for a basic mean grain contamination of $400 \mu \mathrm{g} \cdot \mathrm{kg}^{-1}$ in ploughed plots, which seems to be a realistic value according to published values for France lasting recent years (DGAL, 2004). With this basic reference for scenario 1 , the values used for scenarios 2 and 3 were 800 , and $1200 \mu \mathrm{g} \cdot \mathrm{kg}^{-1}$, respectively. For scenario 1, estimated exposure was lower than the PMTDI value, except for the 97.5th percentile. In contrast, even if only $50 \%$ of the area was subjected to reduced tillage practices (scenario 2), estimated mean exposure was always at least higher than the PMTDI, and estimated exposure was much higher than the PMTDI for direct-drilling over the whole area (scenario 3). Scenario 3 is unlikely in Europe, as deep tillage remains a good means of solving other agronomic problems, such as weed contamination. In contrast, scenario 2 is a realistic possibility, particularly in areas in which agronomic conditions (soil and crop rotation characteristics) do not necessitate annual deep tillage or in conditions in which deep tillage is not recommended, as a means of preventing soil erosion. However, our results should not be used as a direct argument for regulating crop management practices minimise the health risks. The results obtained are highly sensitive to two factors: the basic grain contamination value for scenario 1 , and the ratio $(\mathrm{R})$ of grain DON content for ploughed fields to grain DON content for direct-drilled fields in the same area. Figure 1 presents the values obtained for exposure assessment under scenario 2 , in which grain contamination levels are 100 to 800 $\mu \mathrm{g} . \mathrm{kg}^{-1}$, and $\mathrm{R}$ ranges from 1 to 8 , corresponding to the range reported in previous studies. Even for the highest value of $\mathrm{R}$, mean exposure did not exceed the PMTDI if the basic contamination level was $100 \mu \mathrm{g} \cdot \mathrm{kg}^{-1}$. In contrast, an $\mathrm{R}$ value of 2 was sufficient to attain this PMTDI for mean exposure for contamination values of $400 \mu \mathrm{g} \cdot \mathrm{kg}^{-1}$ and over. We therefore need to determine why these two variables — basic contamination level and $\mathrm{R}$ value - differ 
so greatly from year to year and from place to place. Climate must account for some of this variation (see for example Blaney \& Dodman, 2002; Magan et al., 2002) but other elements of the cropping system may also play a significant role. If farmers choose an appropriate set of techniques (for example, avoiding reduced tillage after a maize crop), they are likely to decrease both the $\mathrm{R}$ value and consumer exposure, even in scenario 2. However, it remains important to increase agronomic knowledge, to improve our understanding of contamination at the regional scale and variations in $R$ values.

We estimated daily consumer exposure according to the three different grain segregation procedures, and for the two datasets (Table 4). For dataset 1 (Table 4a), scenario $a$ resulted in levels of exposure below the PMTDI. Thus, the two alternative scenarios, $b$ and $c$, gave no advantage over the simple blending of grain from all the fields. Moreover, each of these scenarios generated a batch resulting in estimated exposure levels exceeding $1 \mu \mathrm{g} \cdot \mathrm{day}^{-1} \cdot \mathrm{kg}^{-1}$ body weight (batch $\mathrm{M}$ and batch $\mathrm{H}$ for scenarios $b$ an $c$ respectively), except for the mean exposure for scenario $b$.

The results for dataset 2 were very different (Table $4 \mathrm{~b}$ ). The simplest scenario (scenario $a$ ) systematically resulted in exposure levels exceeding the PMTDI. In this dataset, scenarios $b$ and $c$ were of great value as they made it possible to create batches (batch $\mathrm{O}$ for scenario $b$, batch $\mathrm{L}$ for scenario $c$ ) for which estimated exposure was below $1 \mu \mathrm{g} \cdot \mathrm{day}^{-1} \cdot \mathrm{kg}^{-1}$ bodyweight, regardless of consumption value for scenario $c$, and up to the $95^{\text {th }}$ percentile for scenario $b$. Scenario $c$ is potentially the most useful as the creation of batch L not only reduces exposure, but also corresponds to a very large proportion of the fields (90\% of the fields in the sample, whereas only $47 \%$ were retained in batch $\mathrm{O}$ from scenario $b$ ). However, scenario $c$ is also much more difficult to implement based on current knowledge. It requires either the direct 
determination of grain DON content at harvest for each field or the development of a tool for use in the growing crop that can predict final DON content at harvest. Direct measurement remains costly, rapid methods (immunoassays, ELISA tests) are not still totally reliable but the accuracy of methods is generally limited by sampling errors because mycotoxins are not homogeneously distributed in batches (Koch, 2004; Le Boulc'h et al., 2000). However, no operational predictive tool similar to those for predicting other quality characteristics, such as grain protein content (Le Bail et al., 2005), is yet available for predicting DON content. In particular, there is no simple relationship between Fusarium head blight scores in the field and mycotoxin concentrations in grains (Champeil, 2004). Climatic models predicting DON contamination at harvest exist (Hooker et al., 2002; Hook \& Schaafsma, 2003), but their validity domain seems not to be large enough to use them at a wide scale (Champeil, 2004), for instance in Europe. In the absence of technical innovations in this area of predictive tools, scenario $b$ seems satisfactory in terms of the decrease in exposure obtained but remains very costly as a significant fraction of the harvest may be lost to human consumption (as in dataset 2). Scenario $b$ is based on the nature of the previous crop, in the absence of soil tillage data. If a more complete dataset, with more information on crop management and soil and climatic conditions were available, alternative grain segregation scenarios could be tested. Moreover, if informations about the climate were sufficient for at least predict the general pattern of the distribution of DON content that should occur in an area, it could be decided lately if segregation is useful.

Comparing the results obtained with the two datasets highlights the huge importance of the distribution of DON content. Low exposure values were obtained with scenario $a$ for dataset 1 , because a large number of fields accounted for very low levels of contamination, and no very high contamination value was observed. The results obtained for scenarios $b$ and $c$ with 
dataset 2 reflect very high levels of grain contamination for one field in which the preceding crop was maize. These two datasets should be considered only as examples for testing the methodology used. They show that with a grain DON content distribution of this type, the proportion of fields with very high levels of contamination has a major effect. It is therefore of prime importance to determine why some fields are so much more heavily contaminated than others. It would also be of interest to determine how our well two datasets reflect the diversity of real distributions in supply areas. Data are lacking in this domain. Finally, it would be useful to be able to anticipate the situation, based on climatic and cropping system conditions in a given area in a given year. If we knew in advance whether the situation was closer to that for dataset 1 or dataset 2, we would be able to decide whether crop segregation was necessary (scenarios $b$ or $c$ ).

We estimated exposure using a coefficient of 0.44 for the decrease in DON content due to processing. This value is open to debate, as it is known to depend on the type of processing (JEFCA, 2001; Shollenberger et al., 2002; Molinié \& Pfohl-Leszkowicz, 2003). Our results would clearly be affected by changes in this coefficient, but such changes would not invalidate the approach.

Finally, the study demonstrates the difficulties associated with establishing a rational and general system combining cropping system and grain segregation procedure for preventing crop contamination by Fusarium toxins and consumer exposure.

\section{Acknowledgements}

This research was funded by the DGAL (French Ministry of Agriculture) and by INRA. We would also like to thank Alex Edelman \& Associates for editorial advice. 


\section{References}

Blaney, B.J., Dodman R.L., 2002. Production of zearalenone, deoxynivalenol, nivalenol, and acetylated derivated by Australian isolates of Fusarium graminearum and $F$. pseudograminearum in relation to source and culturing conditions. Australian Journal of Agricultural Research 53, 1317-1326.

Champeil, A., 2004. Contribution à la compréhension des effets des systèmes de culture sur l'infection des cultures de blé tendre d'hiver par la fusariose et la contamination des grains par les mycotoxines associées. Thèse de Doctorat de l'INA P-G, INA P-G, Paris.

Champeil, A., Fourbet, J.F., Doré, T., 2004. Influence of cropping system on Fusarium head blight and mycotoxin levels in winter wheat. Crop Protection 23/7, 635-645.

CRÉDOC-AFSSA-DGAL，2000. Enquête INCA individuelle et nationale sur les consommations alimentaires (Coord. J.L.Volatier), Eds Tec\&Doc, Paris.

Derpsch, R., Benites, J.R., 2003. Situation of conservation agriculture in the world. Proc II World congress on conservation agriculture, Iguassu, Brazil, 11-15/08/2003, pp. 125135.

DGAL, 2004. Résultats des plans de surveillance 2002 et 2003 de la contamination des céréales françaises par certaines mycotoxines. Note à usage de service DGAL/SDQPV/SDRRCC/N2004-8285, Ministère de l'agriculture, de l'alimentation, de la pêche et des affaires rurales, Paris.

Dill-Macky, R., Jones R.K., 2000. The effect of previous crop residues and tillage on Fusarium head blight of wheat. Plant Disease 84, 71-76.

Doré, T., Le Bail, M. and Verger, P., 2002. Pratiques agricoles et sécurité sanitaire des aliments en production végétale. Cahiers/Agricultures 11, 177-185. 
Dowell, F.E., Ram, M.S. and Seitz, L.M., 1999. Predicting scab, vomitoxin, and ergosterol in single wheat kernels using near-infrared spectroscopy. Cereal Chemistry 76, 573-576.

Habib, R., Triboi, E., Génard, M. and Le Bail, M., 1997. La nutrition azotée des cultures et la qualité des produits, in B. Nicolardot (ed.). Gestion de l'azote dans les agrosystèmes, INRA, Paris, pp. 141-160.

Hardy, A., Silva Fernandes, A., Speiijers, G., Hans, R., Delcour, M-P., Kuiper, H., Führ, F., Carere, A., Richard-Molard, D. and Thomas, M., 1999. Opinion on the relationship between the use of plant protection products on food plants and the occurrence of mycotoxins in food. Scientific Committee on Plants. European Commission Health and Consumer Protection directorate-General SCP/RESI/063-Final, Brussels, Belgium.

Hooker, D.C. and Schaafsma, A.W., 2003. The DONcast model: using weather variables pre- and post-heading to predict deoxynivalenol content in winter wheat. Aspects of Applied Biology, 68, 117-122.

Hooker, D.C., and Tamburic-Ilincic, L., 2002. Using weather variables pre- and postheading to prodict deoxynivalenol content in winter wheat. Plant disease 86(6), 611-619.

IARC, 1993. Monographs on the evaluation of carcinogenic risks to humans, vol. 56, some naturally occurring substances, food items and constituents, heterocyclic aromatic amines and mycotoxins. World Health Organisation, Lyons, pp 397-433.

International Programme on Chemical Safety/Gems/food Euro workshop on reliable evaluation of low level contamination of food, Appendix 5, Kulmbach, Germany, May 1995.

Ioos, R., Belhadj, A., Menez M. and Faure, A., 2005. The effects of fungicides on Fusarium spp. and Microdochium nivale and their associated trichothecene mycotoxins in French naturally infected cereal grains. Crop Protection, in press. 
JECFA, 2001. Safety evaluation of certain mycotoxins in food, Prepared by the Fiftysixth Meeting of the Joint FAO/WHO Expert Committee on Food Additives, WHO food additives series 47 (WHO Geneva).

Jenny, E., Hecker, A., Kessler, P., Kulling, C. and Forrer, H.R., 2000. Getreidefusariosen: Sortenresistenz und Toxingehalte. Agrarforschung 7, 270-273.

Koch, H.J., Pringas, C., 2004. Overcoming constraints of conservation tillage Fusarium head blight in winter wheat. In "VIII ESA Congress: European agriculture in a global context”, S.E. Jacobsen, C.R. Jensen, J.R. Porter Eds, ESA/KVL, 523-524.

Koch, P., 2004. State of the art of trichothecenes analysis. Toxicology Letters 153, 109-112.

Krebs, H., Dubois, D., Kulling, C., Forrer, H.R., Stret, B., Rieger, S. and Richner W., 2000. Fusarien- und Toxinbelastung des Weizens bei Direktsaat. Agrarforschung 7, 264-268.

Lauren, D.R., Agnew, M.P., Smith, W.A. and Dow, B.W., 1991. A survey of the natural occurence of fusarium mycotoxins in cereals in New Zealand in 1986-1989. Food Addit. Contam.8, 599-605.

Lauren, D.R., Jensen, D.J., Smith, W.A. and Dow, B.W., 1996. Mycotoxins in New Zealand maize: A study of some factors influencing contamination level in grain. N.Z.J. Crop. Hort. Sci. 24, 13-20.

Leblanc J.C., Malmauret, L., Delobel, D. and Verger P., 2002. Simulation of exposure to deoxynivalenol of French consumers of organic and conventional foodstuffs. Regulatory Toxicology and Pharmacology, 36, 149-154.

Le Bail, M., 1997. Maîtrise de la qualité des céréales à l'échelle du bassin d'approvisionnement d'une entreprise de collecte-stockage. Approche agronomique. Thèse de Doctorat de l'INA P-G, INA P-G, Paris. 
Le Bail, M., Makowski, D., 2004. A model-based approach for optimizing segregation of soft wheat in country elevators. European Journal of Agronomy 21, 171-180.

Le Bail, M., Jeuffroy, M.H., Bouchard C. and Barbottin, A., 2005. Is it possible to forecast the grain quality and yield of different varieties of wheat from Minolta SPAD meter measurements? European Journal of Agronomy, in press.

Le Boulc'h, V., Bédouret, S., Poyet, V., Barchietto, T., Pfohl-Leszkowicz, A. and Seng, J.M., 2000. Evaluation de la qualité sanitaire du blé : à propos des mycotoxines et des moyens de les détecter. Phytoma 530, 21-26.

Magan N., Hope R., Colleate A. and Baxter E.S., 2002. Relationship between growth and mycotoxin production by Fusarium species, biocides and environment. European Journal of Plant Pathology 108(7), 685-690.

Molinié, A., Pfohl-Leszkowicz, A., 2003. Les mycotoxines dans les céréales : les points importants de contrôle de la production au stockage, le devenir dans les produits dérivés. Note de l'ASEDIS-SO, $\mathrm{N}^{\circ}$ spécial Mycotoxines.

Neira, M.S., Pacin, A.M., Martinez, E., Molto, G. and Resnik, S.L. 1997. The effect of bakery processing on natural deoxynivalenol contamination. Int. J. Food Microbiol., 37, 21 25.

Schaafsma, A.W., Tamburic-Ilincic, L. and Miller, J.D., 1998. The effect of agronomic practice on the accumulation of deoxynivalenol (DON) in winter wheat fields in Ontario, 1996-1997. In: National Fusarium Head Blight Forum. Chapter 1. Epidemiology and Disease Management, Michigan State University, USA, pp. 7-9.

Shollenberger M., Terry Jara H., Suchy S., Drochner W. and Müller H.M., 2002. Fusarium toxins in wheat flour collected in an area of southwest Germany. Int. J. Food Microbiol. 72, 85-89. 
Scott, P.M. 1997. Multi-year monitoring of Canadian grains and grain-based foods for trichothecenes and zearalenone. Food Addit. Contam.14, 333-339.

Simpson, D.R., Weston, G.E., Turner, J.A., Jennings, P. and Nicholson, P., 2001. Differential control of head blight pathogens of wheat by fungicides and consequences for mycotoxin contamination of grain. Eur. J. Plant Pathol. 107, 421-431.

EU SCOOP reports on Tasks 3.2.10. Assessment of dietary intake of Fusarium toxins by the population of EU member states, September 2003.

Teich, A.H., Hamilton, J.R., 1985. Effect of cultural practices, soil phosphorus, potassium, and $\mathrm{pH}$ on the incidence of Fusarium head blight and deoxynivalenol levels in wheat. Appl. Environ. Microbiol. 79 (6), 1429-1431.

Virender, S. 2000. Grain quality of wheat as influenced by application of nitrogen, climate and cultural practices: a review. Agricultural Reviews 21, 116-120.

WHO, 1990. Selected mycotoxins: Ochratoxin, Trichothecenes, Ergot (EHC 105), Geneva, pp.90-101.

WHO, 2003. Gems/Food regional diets, Food safety issues, Food safety department Revision September 2003. 
Table 1 - Characteristics of the various batches for three scenarios of grain segregation and two datasets

Table 2: Distribution of daily individual wheat flour consumption in the French population $\left(\mathrm{g} \cdot \mathrm{j}^{-1}\right)$

Table 3: Estimation of daily consumer exposure according to crop management practices, with $400 \mu \mathrm{g} \cdot \mathrm{kg}^{-1}$ as the basic level of contamination for scenario 1 .

Table 4: Estimation of consumer exposure according to grain segregation procedure

Figure 1: Assessment of consumer exposure for various values of DON content in grains at a regional scale, and different values of the ratio (DON content in direct-drilled fields)/(DON content in ploughed fields), according to scenario 2. 
Table 1 - Characteristics of the various batches for three scenarios of grain segregation and two datasets

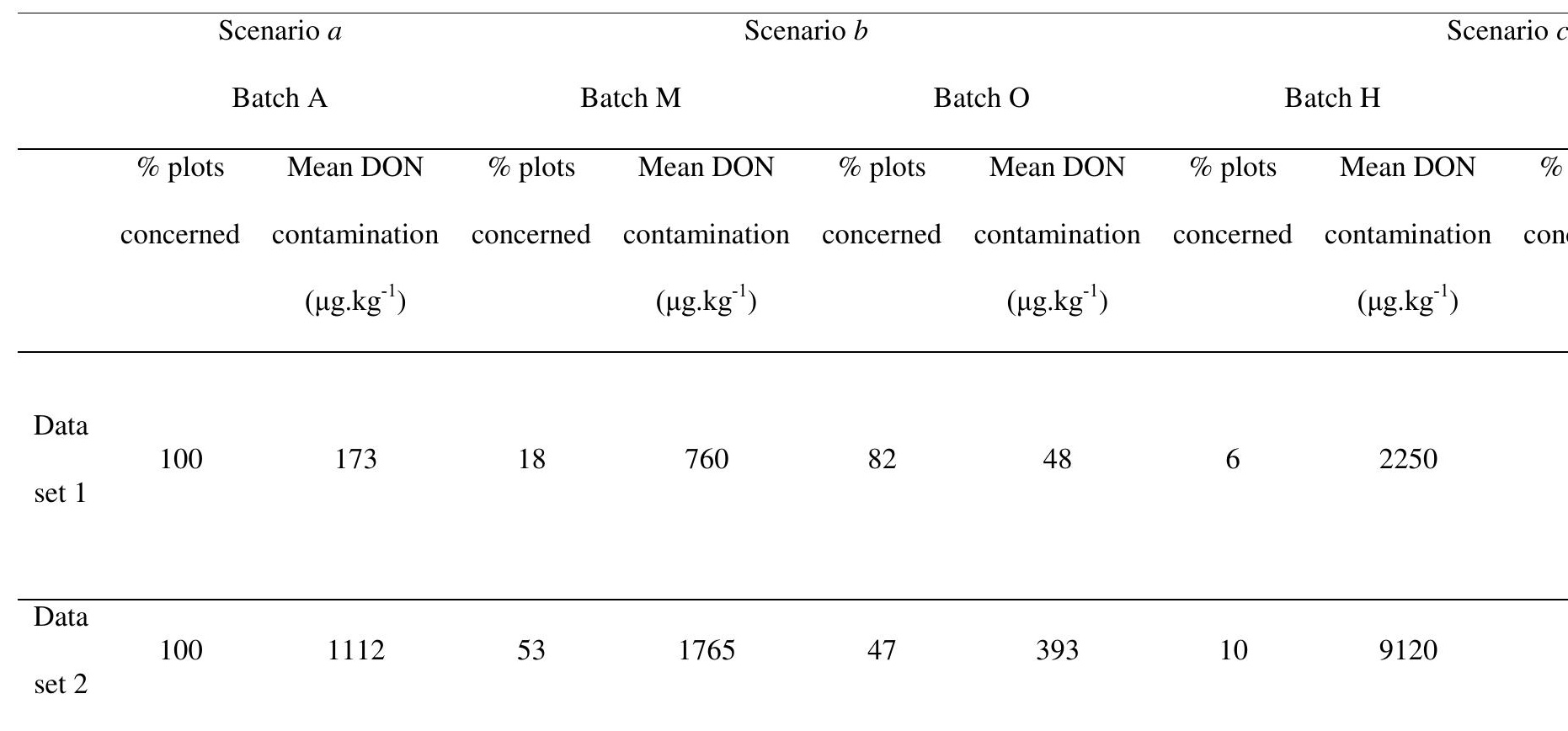


Table 2: Distribution of daily individual wheat flour consumption in the French population (g.j $\left.j^{-1}\right)$

\begin{tabular}{lc}
\hline Mean & 163 \\
Standard Deviation & 85 \\
Median & 147 \\
90th perc. & 264 \\
95th perc. & 313 \\
97.5th perc. & 380
\end{tabular}


Table 3: Estimation of daily consumer exposure according to crop management practices, with $400 \mu \mathrm{g} \cdot \mathrm{kg}^{-1}$ as the basic level of contamination for scenario 1 .

\begin{tabular}{|c|c|c|c|c|}
\hline & \multirow{4}{*}{$\begin{array}{c}\text { Mean exposure } \\
\left(\mu \text { g.day }{ }^{-1} \cdot \mathrm{kg}^{-1} \text { body }\right. \\
\text { weight })\end{array}$} & \multirow{3}{*}{$\begin{array}{c}\text { 90th percentile } \\
\text { exposure } \\
\left(\mu \mathrm{g} \text {.day }{ }^{-1} \cdot \mathrm{kg}^{-1} \text { body }\right.\end{array}$} & \multirow{3}{*}{$\begin{array}{c}\text { 95th percentile } \\
\text { exposure } \\
\left(\mu \mathrm{g} . \mathrm{day}^{-1} \cdot \mathrm{kg}^{-1} \text { body }\right.\end{array}$} & \multirow{3}{*}{$\begin{array}{c}\text { 97.5th percentile } \\
\text { exposure } \\
\left(\mu \text { g. } \text { day }^{-1} \cdot \mathrm{kg}^{-1} \text { body }\right.\end{array}$} \\
\hline & & & & \\
\hline & & & & \\
\hline & & weight) & weight) & weight) \\
\hline Scenario 1 & 0.5 & 0.8 & 0.9 & 1.1 \\
\hline Scenario 2 & 1.0 & 1.5 & 1.8 & 2.2 \\
\hline Scenario 3 & 1.4 & 2.3 & 2.8 & 3.3 \\
\hline
\end{tabular}


Table 4: Estimation of consumer exposure according to grain segregation procedure

\section{a. Dataset 1}

\begin{tabular}{|c|c|c|c|c|c|}
\hline & & & 90th percentile & 95th percentile & $97.5^{\text {th }}$ percentile \\
\hline & & Mean exposure & exposure & exposure & exposure \\
\hline & & $\left(\mu \mathrm{g} \cdot \mathrm{day}^{-1} \cdot \mathrm{kg}^{-1}\right.$ & $\left(\mu \mathrm{g} \cdot\right.$ day $^{-1} \cdot \mathrm{kg}^{-1}$ & $\left(\mu \mathrm{g} \cdot \mathrm{day}^{-1} \cdot \mathrm{kg}^{-1}\right.$ & $\left(\mu\right.$ g.day ${ }^{-1} \cdot \mathrm{kg}^{-1}$ \\
\hline & & body weight) & body weight) & body weight) & body weight) \\
\hline Scenario $a$ & Batch A & 0.2 & 0.3 & 0.4 & 0.5 \\
\hline & Batch M & 0.9 & 1.5 & 1.7 & 2.1 \\
\hline Scenario $b$ & Batch O & 0.1 & 0.1 & 0.1 & 0.1 \\
\hline & Batch H & 2.7 & 4.4 & 5.2 & 6.3 \\
\hline Scenario $c$ & Batch L & 0.1 & 0.1 & 0.1 & 0.1 \\
\hline b. Dataset & & & & & \\
\hline & & & & & $97.5^{\text {th }}$ \\
\hline & & & 90th percentile & $95^{\text {th }}$ percentile & percentile \\
\hline & & Mean exposure & exposure & exposure & exposure \\
\hline & & $\left(\mu \mathrm{g} \cdot\right.$ day $^{-1} \cdot \mathrm{kg}^{-1}$ & $\left(\mu \mathrm{g} \cdot\right.$ day $^{-1} \cdot \mathrm{kg}^{-1}$ body & $\left(\mu \mathrm{g} \cdot\right.$ day $^{-1} \cdot \mathrm{kg}^{-1}$ & $\left(\mu \mathrm{g} \cdot \mathrm{day}^{-1} \cdot \mathrm{kg}^{-1}\right.$ \\
\hline & & body weight) & weight) & body weight) & body weight) \\
\hline Scenario $a$ & Batch A & 1.3 & 2.2 & 2.6 & 3.1 \\
\hline & Batch M & 2.1 & 3.4 & 4.1 & 4.9 \\
\hline Scenario $b$ & Batch O & 0.5 & 0.8 & 0.9 & 1.1 \\
\hline & Batch H & 10.9 & 17.7 & 20.9 & 25.4 \\
\hline Scenario $c$ & Batch L & 0.3 & 0.5 & 0.6 & 0.7 \\
\hline
\end{tabular}


Figure 1: Assessment of consumer exposure for various values of DON content in grains at a regional scale, and different values of the ratio (DON content in direct-drilled fields)/(DON content in ploughed fields), according to scenario 2 .

a - Mean exposure

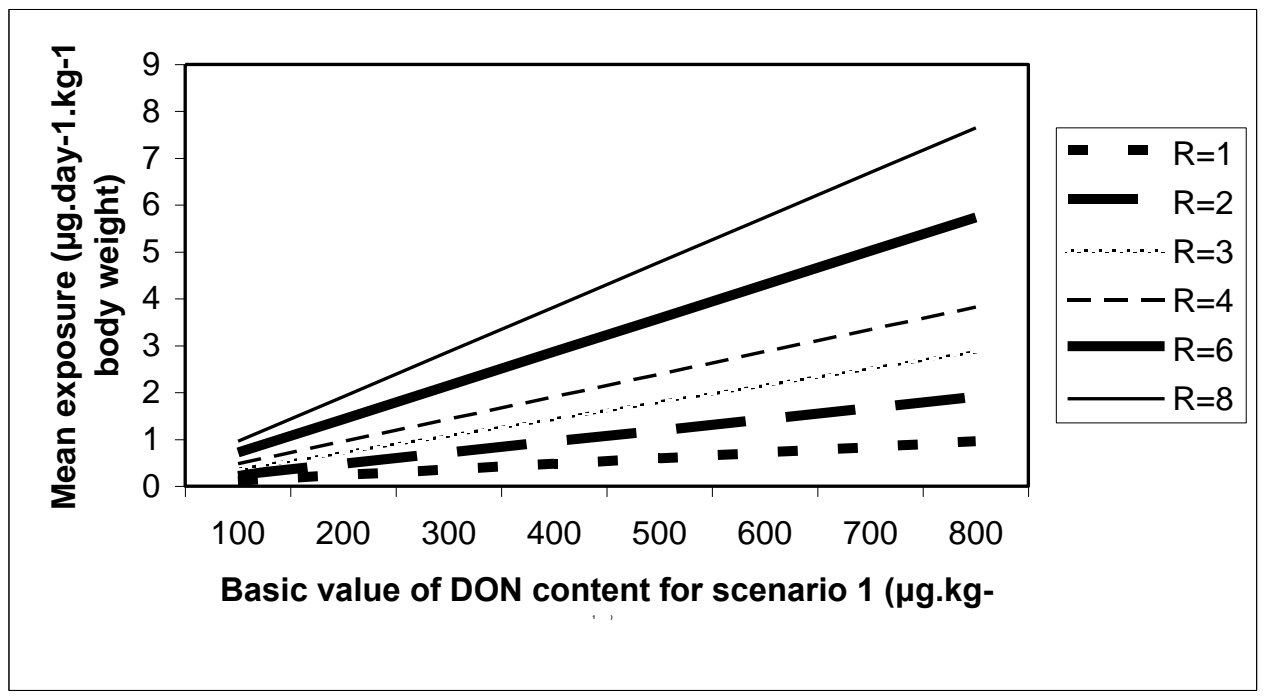

$\mathrm{b}-$ Exposure for the $95^{\text {th }}$ percentile

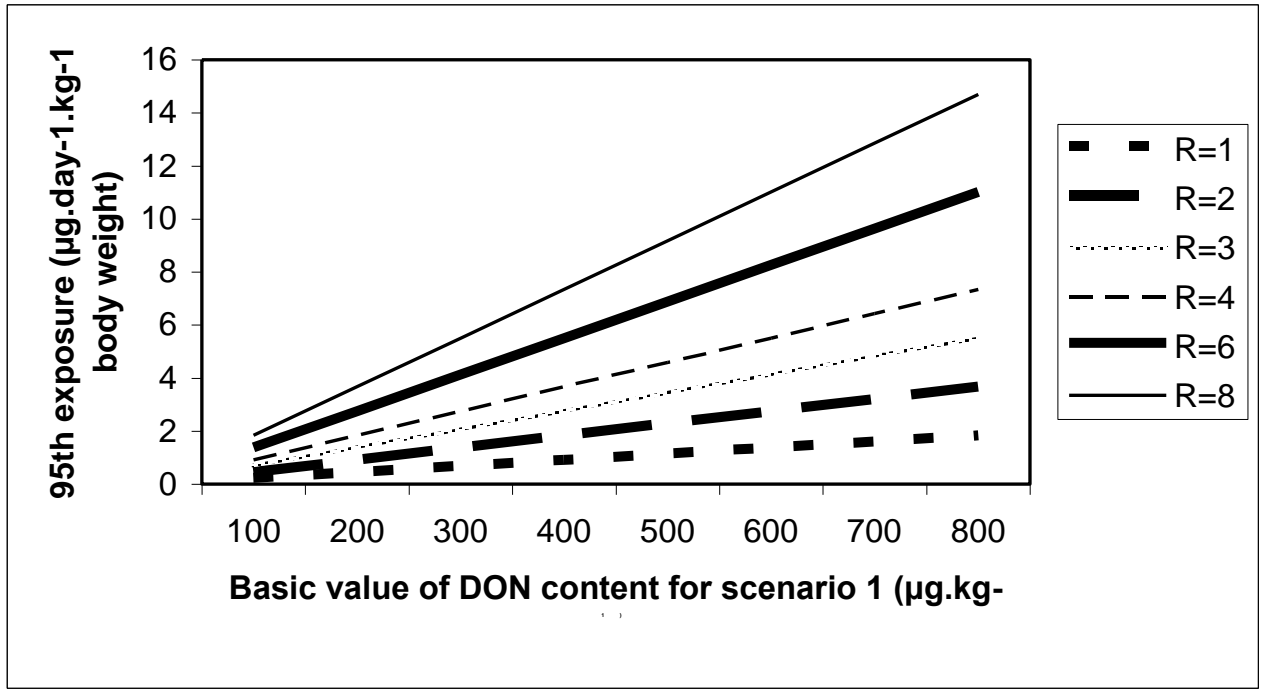

